\title{
Застосування режиму штучної вентиляції легень neurally adjusted ventilatory assist у новонароджених з гіпоксично-ішемічною енцефалопатією
}

\author{
Сурков Д. М.
}

\author{
К3 «Дніпропетровська обласна дитяча клінічна лікарня ДОР», м. Дніпро, Україна
}

\begin{abstract}
Резюме. Респіраторна підтримка вважається одним з головних компонентів інтенсивної терапії доношених новонароджених з помірною або тяжкою гіпоксично-ішемічною енцефалопатією (ГІЕ). Більшість авторів рекомендують проведення штучної вентиляції легень протягом періоду лікувальної гіпотермії та раннього періоду після зігрівання. Традиційно в новонароджених застосовується вентиляція з контролем тиску в дихальних шляхах, недоліком якої є можливі значні коливання рівня $\mathrm{CO}_{2}$, що впливає на церебральну перфузію. Альтернативою може бути новітній режим вентиляції Neurally Adjusted Ventilatory Assist (NAVA). Iснує певна кількість досліджень застосування режиму NAVA в немовлят, як доношених, так і недоношених, але його вплив на церебральну перфузію порівняно з традиційними режимами не вивчений.
\end{abstract}

Мета роботи. Порівняти вплив NAVA та інших режимів штучної вентиляції легень на стан мозкового кровотоку в гострому періоді ГІЕ в доношених новонароджених.

Матеріали і методи. Досліджено 205 доношених новонароджених з ГІЕ за шкалою Sarnat II-III ст. у терміні $\leq 72$ годин після пологів. Немовлята були розподілені методом простої відкритої рандомізації за режимами штучної вентиляції легень на групу NAVA $(\mathrm{n}=18)$ та групу контролю $(\mathrm{n}=187)$, яку в подальшому було стратифіковано на підгрупи із застосуванням режимів Pressure Control (PC) $(\mathrm{n}=152)$, Synchronized Intermittent Mandatory Ventilation / Pressure Support Ventilation (SIMV/PSV) $(n=16)$ та Pressure Regulated Volume Control $(\mathrm{PRVC})(\mathrm{n}=19)$. Проведений порівняльний аналіз впливу NAVA та інших режимів вентиляції на стан церебральної перфузії в гострому періоді неонатальної ГІЕ.

Результати та обговорення. Порівняно з традиційними режимами вентиляції PC, SIMV/PSV та PRVC на фоні респіраторної підтримки в режимі NAVA отримані достовірно кращі показники доплерівських індексів мозкового кровотоку RI $(0,66[0,58-0,72]$ проти $0,70[0,67-0,74], \mathrm{p}=0,021)$ та PI $(1,2[1,0-1,40]$ проти 1,3 $[1,2-1,5], \mathrm{p}=0,032)$ на 3 -й день дослідження, наприкінці періоду лікувальної гіпотермії та початку зігрівання. Проведений у подальшому мультиваріантний дисперсійний аналіз ANOVA (analysis of variance) підтвердив позитивний вплив режиму NAVA на церебральну перфузію $(\mathrm{p}=0,009)$, але не виявив достовірного зв'язку з індексами мозкового кровотоку при застосуванні режимів PC $(\mathrm{p}=0,140)$, SIMV/PSV $(\mathrm{p}=0,446)$ Ta PRVC $(\mathrm{p}=0,601)$.

Висновки. Режим вентиляції NAVA має кращий вплив на індекси церебральної перфузії в доношених новонароджених у гострому періоді ГIЕ порівняно з традиційними режимами PC, SIMV/PSV та PRVC.

Ключові слова: гіпоксія, ішемія, енцефалопатія, вентилящія легень, індекс резистентності, NAVA.

Вступ. Респіраторна підтримка вважається одним із головних компонентів інтенсивної терапії доношених новонароджених з помірною або тяжкою гіпоксичноішемічною енцефалопатією (ГІЕ). Спонтанне дихання $з$ підтримкою Continuous Positive Airway Pressure (СРАР) розглядається тільки при легкій формі ГІЕ або як компонент респіраторної підтримки після екстубації трахеї $[1,2]$. Більшість авторів рекомендують проведення штучної вентиляції легень (ШВЛ) протягом періоду лікувальної гіпотермії та раннього періоду після зігрівання в середньому 3-5 днів [3-5].

Традиційно в новонароджених застосовується вентиляція з контролем тиску в дихальних шляхах на відміну від дорослих, для яких частіше застосовується вентиляція з контролем об’єму. Перевагою ШВЛ з контролем тиску (Pressure Control Ventilation, РС) вважається рівномірне розподілення газу в негомогенних легенях, де ділянки ателектазів чергуються з легеневою тканиною з низьким комплаєнсом та високою резистентністю [6]. Недоліком такого підходу стосовно церебральної перфузії є той феномен, що дихальний об’єм стає похідною величиною, що може призводити до значних коливань рівня $\mathrm{CO}_{2}[7,8]$. 3 іншого боку, вентиляція з контролем об'єму (Volume Control Ventilation, VC) хоч і забезпечує сталий хвилинний об'єм вентиляції та щільний контроль гіпокапнії або гіперкапнії, проте пов'язується в новонароджених з великим відсотком вентилятор-асоційованих ускладнень, баротравмою та синдромом витоку повітря (пневмоторакс, пневмоперикард) $[9,10]$. Один із напрямів вирішення 
цієї проблеми - розробка виробниками так званих гібридних режимів, регульованих за тиском, але з цільовим контролем дихального об’єму (Volume Targeted Ventilation) [11-13].

Серед режимів штучної вентиляції легень, що застосовуються в новонароджених, найбільш поширеними є такі:

- Pressure Control Ventilation, РC - вентиляція 3 контролем тиску в дихальних шляхах [14-16];

- Synchronized Intermittent Mandatory Ventilation, SIMV - синхронізована періодична примусова вентиляція $[17,18]$;

- Pressure Support Ventilation, PSV - вентиляція з підтримкою тиску в дихальних шляхах [19-21];

- Pressure Regulated Volume Control, PRVC - вентиляція з контролем об'єму та регулюванням тиску в дихальних шляхах $[12,13,22]$.

Альтернативою може бути новітній режим вентиляціï Neurally Adjusted Ventilatory Assist (NAVA), який грунтується на реєстрації трансдіафрагмального збудження n. phrenicus (Electrical activity of diaphragm, Edi-сигнал), вимірюванні його пікової амплітуди та розрахунку підтримки тиску в дихальних шляхах залежно від величини спонтанного дихального патерну. Протягом дихального циклу встановлюється постійна величина Positive End Expiratory Pressure (PEEP), а величина Pressure Support розраховується як добуток величини сигналу Edi $(\mu \mathrm{V})$ на величину тиска підтримки (NAVA level, см вод. ст.) [23, 24]. Перевагами цього режиму вважають:

- оптимальну синхронізацію роботи апарата ШВЛ з пацієнтом [25];

- зменшення потреби в седативних препаратах [26];

- відсутність пікових коливань рівня $\mathrm{CO}_{2}$, оскільки хвилинний об’єм дихання повністю залежить від дихальної активності пацієнта [27];

- зменшення вентилятор-асоційованих ускладнень [28];

- скорочення тривалості штучної вентиляції легень [29];

- легке відлучення від ШВЛ, менший відсоток реінтубацій [30].

Існує багато досліджень застосування режиму NAVA в немовлят, як доношених, так і недоношених [31-34], але його вплив на церебральну перфузію порівняно 3 традиційними режимами не вивчений.

Мета роботи. Порівняти вплив NAVA та інших режимів штучної вентиляції легень на стан мозкового кровотоку в гострому періоді ГІЕ у доношених новонароджених.

Матеріали і методи. Було проведене проспективне одноцентрове рандомізоване контрольоване дослідження в 205 доношених немовлят, які протягом 2012-2016 рр. перебували на лікуванні у відділенні анестезіології та інтенсивної терапії для новонародже- них (BАITH) К3 «Дніпропетровська обласна дитяча клінічна лікарня ДОР» 3 діагнозом «Важка гіпоксично-ішемічна енцефалопатія» (Р91.6 за Міжнародним класифікатором хвороб, МKX-10).

Критерії включення: доношені новонароджені гестаційного віку 37-42 тижнів та масою тіла $\geq 2500$ г із оцінкою за шкалою Апгар при народженні менше 7 балів та оцінкою за шкалою Sarnat II-III ст., післянатальний вік - до 72 годин після пологів.

Критерії виключення: уроджені вади розвитку серця та центральної нервової системи, ранній неонатальний сепсис, нейроінфекції, підтверджені пологові травми, гестаційний вік $<37$ тижнів, маса тіла при народженні $<2500$ г, післянатальний вік - понад 72 години після пологів.

Діагноз «Гіпоксично-ішемічна енцефалопатія» встановлювався відповідно до Наказу МО3 України від 08.06.2007 р. № 312 «Про затвердження клінічного Протоколу з первинної реанімації та післяреанімаційної допомоги новонародженим» та Наказу МОЗ України від 28.03.2014 р. № 225, яким затверджено Уніфікований клінічний протокол «Початкова, реанімаційна і післяреанімаційна допомога новонародженим в Україні» за шкалою Sarnat (Sarnat H. B., Sarnat M. S. (1976) у модифікації Hill A., Volpe I. I. (1994)).

Етапи дослідження: перший день лікування, на 2-гу та 3-тю добу дослідження.

Усім дітям проводилась рутинна інтенсивна терапія відповідно до затвердженого Наказом МО3 України від 28.03.2014 р. № 225 Уніфікованого клінічного протоколу «Початкова, реанімаційна і післяреанімаційна допомога новонародженим в Україні», що включала раннє застосування терапевтичної гіпотермії $33-35^{\circ} \mathrm{C}$ протягом 72 годин.

Методом відкритої простої рандомізації новонароджені були розподілені на групу із застосуванням NAVA $(n=18)$ і групу контролю $(\mathrm{n}=187)$, пацієнтам якої проводили такі режими вентиляції, як РС $(\mathrm{n}=152), \operatorname{SIMV} / \operatorname{PSV}(\mathrm{n}=16)$ та $\operatorname{PRVC}(\mathrm{n}=19)$.

На всіх етапах дослідження немовлятам проводилась стандартна нейросонографія 3 визначенням лінійних швидкостей мозкового кровотоку (максимальна систолічна швидкість (Vs), см/с; максимальна діастолічна швидкість (Vd), см/с; середня швидкість $(\mathrm{Vm}), \mathrm{cm} / \mathrm{c})$ у передній мозковій артерії (Arteria Cerebri Anterior, ACA) із подальшим розрахунком індексу резистентності мозкових судин Пурсело (Pourcelot Resistive Index) на 3-й день лікування, під час закінчення періоду лікувальної гіпотермії та на початку зігрівання немовлят як найбільш прогностично значущого стосовно наслідків ГІЕ [35-38]:

$$
\mathrm{RI}=(\mathrm{Vs}-\mathrm{Vd}) / \mathrm{Vs}
$$

Статистичну обробку матеріалів дослідження було проведено з використанням пакету програмного за- 
безпечення JASP 0.9.0.1 (Amsterdam, The Netherlands, 2018) відповідно до загальноприйнятих стандартів математичної статистики. Перед статистичною обробкою всі дані були перевірені на нормальність розподілу із застосуванням W-тесту Шапіро - Вілкса. Для параметричних даних первинна статична обробка включала розрахунок середньої величини та стандартного відхилення (Mean \pm SD). Для непараметричних даних первинна статистична обробка даних включала розрахунок медіани M, 25 та $75 \%$ персентилів. Для статистичного порівняння значень досліджуваних груп використовували U-критерій Манна - Уітні (Mann Whitney U-test). Для визначення достовірності впливу на досліджуваний результативний показник кожного iз факторів був проведений мультиваріантний дисперсійний аналіз ANOVA (analysis of variance). Критерій $\mathrm{p}<0,05$ був прийнятий як значущий у всіх тестах.

Результати та їх обговорення. Усього було проаналізовано результати лікування 205 доношених новонароджених, середній гестаційний вік склав 39,6 \pm 1,4 тижня (37-42), вага при народженні - $3573 \pm 549$ г (2440$5300)$. За статевою ознакою 128 немовлят $(62,4 \%)$ були хлопчики та 77 (37,6 \%) - дівчатка. Протягом 0-6 годин від народження до відділення надійшли 56 дітей $(27,4 \%)$, протягом 6-24 годин - 144 (70,2\%), протягом 24-72 годин - 5 (2,4\%). Протягом 28 днів летальність серед 205 дітей склала 3 (1,46\%). У 82 випадках (40 \%) відбулися перші пологи, у 123 (60\%) - повторні. У 42 випадках $(20,5 \%)$ проводився кесарів розтин, при цьому 17 (40,5 \%) дітей народжені при перших пологах та $25(59,5 \%)$ - при повторних пологах $(\mathrm{p}=0,994)$. Оцінка за Апгар склала на 1 хв 4,04 $\pm 2,27$ балів; на 5 хв $-5,88 \pm 1,82$ бали; на 20 хв $(\mathrm{n}=56)-6,29 \pm 1,19$ балів. При надходженні в дітей визначався рівень лактату, який склав 7,93 $\pm 5,44$ [0,9-25,1] ммоль/л, що до-

\section{Таблиця 1}

Параметри вентиляиії та газообміну на 2-й день дослідження в новонароджених, які перебували на вентиляції в режимі NAVA, порівняно з групою контролю

\begin{tabular}{|c|c|c|c|}
\hline \multirow[b]{2}{*}{ Показники } & $\begin{array}{c}\text { Група NAVA } \\
(n=18)\end{array}$ & $\begin{array}{c}\text { Група контролю } \\
\text { (n = 187) }\end{array}$ & \multirow[b]{2}{*}{ p } \\
\hline & \multicolumn{2}{|c|}{$M \pm S D$} & \\
\hline $\mathrm{FiO}_{2}, \%$ & $0,25 \pm 0,04$ & $0,28 \pm 0,1$ & 0,139 \\
\hline МАР, см вод. ст. & $8,8 \pm 1,6$ & $9,8 \pm 2,3$ & 0,066 \\
\hline $\mathrm{Ol}$ & $2,05 \pm 1,03$ & $3,3 \pm 1,3$ & 0,009 \\
\hline $\mathrm{VI}$ & $19,4 \pm 10,6$ & $24,9 \pm 18,7$ & 0,238 \\
\hline рСО, мм рт. ст. & $40,9 \pm 6,5$ & $36,3 \pm 14,5$ & 0,021 \\
\hline $\mathrm{pH}$ & $7,43 \pm 0,09$ & $7,37 \pm 0,05$ & 0,006 \\
\hline
\end{tabular}

Примітка. $\mathrm{FiO}_{2}$ - фракція кисню в газовій суміші на вдиху; MAP - Mean Airway Pressure, середній тиск у дихальних шляхах; OI - індекс оксигенації; VI - вентиляційний індекс; $\mathrm{pCO}_{2}$ - парціальний тиск діоксиду вуглецю в крові. зволило підтвердити факт перенесеної анте- та інтранатальної гіпоксії.

У 1-й день дослідження не виявлено статистично достовірних відмінностей між режимами вентиляції. Порівняння базових параметрів вентиляції та газообміну в групі NAVA і групі контролю на 2-й день дослідження наведені в таблиці 1.

Незважаючи на відсутність різниці залежно від дотації кисню, на 2-й день лікування в пацієнтів з групи NAVA спостерігався достовірно нижчий індекс оксигенації $(\mathrm{p}=0,009)$. Цікавою виявилася закономірність, за якої при достовірно вищому показнику $\mathrm{pCO}_{2}(\mathrm{p}=0,021)$ у групі NAVA одночасно виявився більш високий рівень pH $(\mathrm{p}=0,006)$, що, вірогідно, свідчило про кращу метаболічну компенсацію. Як це вплинуло на стан церебрального кровотоку, буде розглянуто нижче.

Порівняння базових параметрів вентиляції та газообміну в групі NAVA і групі контролю на 3-й день дослідження представлені в таблиці 2.

Уже на 3-й день виявилась низка статистично значущих відмінностей між NAVA та іншими режимами вентиляції. Так, діти з групи NAVA мали достовірно нижчу залежність від дотації кисню $(\mathrm{p}=0,047)$, відповідно, нижчі індекси оксигенації $(\mathrm{p}<0,001)$ і вентиляції ( $\mathrm{p}=$ $0,038)$, причому це досягалось меншим тиском у дихальних шляхах $(\mathrm{p}=0,001)$. Але, на відміну від 2-го дня, на 3-й день не було виявлено статистично достовірних відмінностей відносно рівня $\mathrm{pCO}_{2}$ та $\mathrm{pH}$. Пояснити такі відмінності в показниках вентиляції та газового складу крові можливо кращою синхронізацією з пацієнтами, але, беручи до уваги зменшення OI та VI, на фоні вентиляції NAVA мала місце оптимізація вентиляційно-перфузійних співвідношень у легенях за рахунок зменшення МАР і покращення венозного повернення крові до серця, що поліпшувало системну гемодинаміку.

Порівняння базових параметрів вентиляції та газообміну в групі NAVA і групі контролю на 5-й день дослідження представлені в таблиці 3.

\section{Таблиця 2}

Параметри вентиляиії та газообміну на 3-й день дослідження в новонароджених, які перебували на вентиляиії в режимі NAVA, порівняно з групою контролю

\begin{tabular}{|c|c|c|c|}
\hline \multirow[b]{2}{*}{ Показники } & $\begin{array}{c}\text { Група NAVA } \\
(\mathrm{n}=18)\end{array}$ & $\begin{array}{c}\text { Група контролю } \\
\text { (n= 187) }\end{array}$ & \multirow[b]{2}{*}{ p } \\
\hline & \multicolumn{2}{|c|}{$M \pm S D$} & \\
\hline $\mathrm{FiO}_{2}, \%$ & $0,24 \pm 0,03$ & $0,28 \pm 0,01$ & 0,047 \\
\hline МАР, см вод. ст. & $7,1 \pm 1,9$ & $9,3 \pm 2,4$ & 0,001 \\
\hline OI & $1,87 \pm 1,5$ & $3,2 \pm 2,9$ & $<0,001$ \\
\hline $\mathrm{VI}$ & $14,9 \pm 7,9$ & $24,7 \pm 4,8$ & 0,038 \\
\hline рCO $_{2}$, мм рт. ст. & $40,0 \pm 7,9$ & $39,4 \pm 14,6$ & 0,428 \\
\hline $\mathrm{pH}$ & $7,42 \pm 0,05$ & $7,45 \pm 0,08$ & 0,066 \\
\hline
\end{tabular}




\section{Таблиця 3}

Параметри вентиляції та газообміну на 5-й день дослідження в новонароджених, які перебували на вентиляції в режимі NAVA, порівняно з групою контролю

\begin{tabular}{lccc} 
& $\begin{array}{c}\text { Група NAVA } \\
(\mathbf{n}=\mathbf{1 8})\end{array}$ & $\begin{array}{c}\text { Група контролю } \\
(\mathbf{n}=\mathbf{1 8 7})\end{array}$ & $\mathbf{p}$ \\
\cline { 2 - 3 } Показники & \multicolumn{2}{c}{$\mathbf{M} \pm \mathrm{SD}$} & $\mathbf{p}$ \\
\hline $\mathrm{FiO}_{2}, \%$ & $0,24 \pm 0,03$ & $0,27 \pm 0,06$ & 0,290 \\
\hline $\mathrm{MAP}$, см вод. ст. & $8,4 \pm 1,6$ & $8,4 \pm 1,9$ & 0,787 \\
\hline $\mathrm{OI}$ & $1,9 \pm 1,0$ & $3,1 \pm 2,4$ & 0,082 \\
\hline $\mathrm{VI}$ & $20,9 \pm 11,0$ & $20,5 \pm 13,9$ & 0,710 \\
\hline $\mathrm{pCO}$, мм рт. ст. & $48,9 \pm 5,5$ & $38,9 \pm 9,0$ & 0,002 \\
\hline $\mathrm{pH}$ & $7,38 \pm 0,05$ & $7,44 \pm 0,08$ & 0,011
\end{tabular}

На 5-й день дослідження майже всі показники не мали статистично значущих відмінностей поміж групами та перебували в межах цільових референсних значень. Але зберігалась відмінність між групами стосовно $\mathrm{pCO}_{2}(\mathrm{p}=0,002)$ та $\mathrm{pH}(\mathrm{p}=0,011)$, причому в групі NAVA це було в межах швидше пермісивної гіперкапнії, ніж нормокапнії. Зважаючи на той факт, що в NAVA всі параметри вентиляції повністю контролюються пацієнтом і залежать від сигналу електричного збудження діафрагми, залишається невирішеним питання, наскільки загально рекомендовані референсні норми рівня рСО 2 відповідають метаболічним потребам і принципам регуляції мозкового кровотоку в новонароджених у гострому періоді помірної та тяжкої ГІЕ.

Тому наступним етапом наукового пошуку було порівняти та з'ясувати вплив NAVA та інших режимів на стан мозкового кровотоку. Оскільки вже була доведена найбільша прогностична значущість індексів, що характеризують стан авторегуляції церебральних судин, на 3-й день лікування та було з'ясовано, що саме на цей етап припадають більшість достовірних відмінностей між NAVA й іншими режимами механічної вентиляції, логічним рішенням було порівняти їх вплив на доплерівські індекси мозкової перфузії саме на цьому етапі.

Порівняння впливу режиму вентиляції NAVA та інших режимів контрольної групи на доплерівські індекси мозкового кровотоку наприкінці 72-годинного періоду лікувальної гіпотермії та початку зігрівання наведено в таблиці 4 і таблиці 5.

Наведені в таблиці 4 дані демонструють достовірно вищі показники як RI (p=0,021), так і PI $(\mathrm{p}=0,032)$ на 3-й день у досліджуваній групі із застосуванням режиму NAVA на 2-й день порівняно з групою контролю. Це свідчить про менший негативний вплив вентиляції на церебральний кровообіг при ії проведенні в режимі

\section{Таблиця 4}

Порівняння доплерівських індексів мозкової перфузії на 3-й день лікування при застосуванні NAVA та інших режимів штучної вентиляції легень з контролем тиску на 2-й день дослідження

\begin{tabular}{lccc} 
& $\begin{array}{c}\text { Група контролю } \\
(\mathbf{n = 1 8 7 )}\end{array}$ & $\begin{array}{c}\text { Група NAVA } \\
(\mathbf{n = 1 8 )}\end{array}$ & \\
\cline { 2 - 3 } & \multicolumn{2}{c}{ Median [25\%-75\%] } & p \\
\hline $\begin{array}{l}\mathrm{R} \text { I на 3-й день } \\
\text { лікування }\end{array}$ & $0,66[0,58-0,72]$ & $0,70[0,67-0,74]$ & 0,021 \\
\hline $\begin{array}{l}\mathrm{PI} \text { на 3-й день } \\
\text { лікування }\end{array}$ & $1,2[1,0-1,40]$ & $1,3[1,2-1,5]$ & 0,032 \\
& & &
\end{tabular}

Примітка. У [ ] - міжквартильний діапазон індивідуальних коливань; $\mathrm{p}$ - достовірність відмінності порівняно з контролем.

\section{Таблиця 5}

Порівняння доплерівських індексів мозкової перфузії на 3-й день лікування при застосуванні NAVA та інших режимів штучної вентиляції легень з контролем тиску на 3-й день дослідження

\begin{tabular}{lccc} 
& $\begin{array}{c}\text { Група контролю } \\
\text { (n= 187) }\end{array}$ & $\begin{array}{c}\text { Група NAVA } \\
(\mathbf{n = 1 8 )}\end{array}$ & \\
\cline { 2 - 3 } & \multicolumn{2}{c}{ Median [25\%-75\%] } & p \\
\hline $\begin{array}{l}\mathrm{RI} \text { на 3-й день } \\
\text { лікування }\end{array}$ & $0,66[0,58-0,72]$ & $0,70[0,67-0,74]$ & 0,040 \\
\hline $\begin{array}{l}\text { PI на 3-й день } \\
\text { лікування }\end{array}$ & $1,2[1,0-1,40]$ & $1,3[1,2-1,5]$ & 0,067 \\
\end{tabular}

Примітка. $\mathrm{p}$ - достовірність відмінності порівняно з контролем.

Neurally Adjusted Ventilatory Assist, ніж у традиційних режимах PC, SIMV/PSV або PRVC.

Наведені в таблиці 5 дані демонструють достовірно вищі показники RI $(\mathrm{p}=0,040)$ на 3 -й день у досліджуваній групі із застосуванням режиму NAVA на 3-й день порівняно з групою контролю. Але стосовно індексу РI відмінність уже виявилась статистично недостовірною $(\mathrm{p}=0,067)$. Таким чином, підсумовуючи результати аналізу, наведені в таблицях 4 та 5, можна узагальнити, що порівняно з традиційними режимами PC, SIMV/ PSV або PRVC застосування Neurally Adjusted Ventilatory Assist на 2-й день лікування достовірно корелювало з кращими показниками доплерівських індексів церебрального кровообігу як на 2-й день, так і на 3-й, наступний, день спостереження.

Для перевірки достовірності відмінності поміж режимами був проведений мультиваріантний дисперсійний аналіз ANOVA впливу режимів вентиляції NAVA на показники RI як на 2-й, так і на 3-й день лікування. 


\section{Таблиця 6}

Вплив застосування режиму NAVA $(n=18)$ на показники RI на 2-й і на 3-й день лікування

\begin{tabular}{lccccc} 
& $\begin{array}{c}\text { Сума } \\
\text { площі } \\
\text { відхилень }\end{array}$ & $\begin{array}{c}\text { Середня } \\
\text { Перемінні }\end{array}$ & $\begin{array}{c}\text { площа } \\
\text { відхилень }\end{array}$ & $\mathbf{F}$ & $\mathbf{p}$ \\
\hline Ефекти в групах пацієнтів & & & & \\
\hline $\mathrm{RI}$ & 0,020 & 1 & 0,020 & 1,935 & 0,166 \\
\hline $\begin{array}{l}\text { RI· NAVA на 2-й } \\
\text { день }\end{array}$ & $3,781 \mathrm{e}-4$ & 1 & $3,781 \mathrm{e}-4$ & 0,037 & 0,847 \\
\hline Залишок & 1,710 & 169 & 0,010 & & - \\
\hline Ефекти між групами пацієнтів & & & & \\
\hline NAVA на 2-й день & 0,095 & 1 & 0,095 & 6,904 & 0,009 \\
\hline Залишок & 2,314 & 169 & 0,014 & & -
\end{tabular}

Результати тесту впливу режиму вентиляції NAVA на 2-й день на показники RI на 2-й і на 3-й день лікування наведені в таблиці 6 .

Аналіз даних у таблиці 6 продемонстрував відсутність достовірних відмінностей індексу RI між групою немовлят, що перебували на вентиляції NAVA, i контрольною групою, в якій застосовували інші традиційні режими $(\mathrm{p}=0,166)$. Крім того, при проведенні вентиляції NAVA не знайдено достовірної різниці відносно індексу RI на 2-й та 3-й день спостереження $(\mathrm{p}=0,847)$. Проте наступний тест ANOVA виявив статистично значущу відмінність індексу RI саме між досліджуваними групами $(\mathrm{p}=0,009)$.

Результати мультиваріантного дисперсійного аналізу ступеня впливу режиму NAVA на зміни індексу RI на 2-й та 3-й день спостереження порівняно з 0-гіпотезою наведені на рисунку 1.

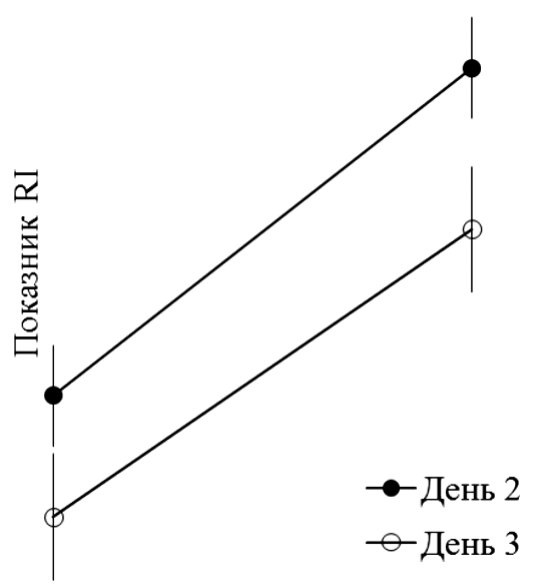

NAVA на 2-й день (0 - ні, 1 - так)

Рисунок 1. Порівняльний аналіз впливу режиму NAVA на зміни індексу RI на 2-й та 3-й день спостереження

\section{Таблиця 7}

Вплив застосування режиму SIMV/PSV $(n=16)$ на показники RI на 2-й і 3-й день лікування

\begin{tabular}{lccccc} 
& $\begin{array}{c}\text { Сума } \\
\text { площі } \\
\text { відхилень }\end{array}$ & $\begin{array}{c}\text { Середня } \\
\text { Перемінні }\end{array}$ & $\begin{array}{c}\text { площа } \\
\text { відхилень }\end{array}$ & $\mathbf{F}$ & $\mathbf{p}$ \\
\hline $\begin{array}{l}\text { Ефекти в групах пацієнтів } \\
\text { RI }\end{array}$ & 0,005 & 1 & 0,005 & 0,449 & 0,504 \\
\hline $\begin{array}{l}\text { RI·SIMV/PSV на } \\
\text { 2-й день }\end{array}$ & 0,005 & 1 & 0,005 & 0,449 & 0,504 \\
\hline Залишок & 1,706 & 169 & 0,010 & & - \\
\hline $\begin{array}{l}\text { Ефекти між групами пацієнтів } \\
\text { SIMV/PSV на }\end{array}$ & 0,008 & 1 & 0,008 & 0,583 & 0,446 \\
2-й день & 2,400 & 169 & 0,014 & & -
\end{tabular}

Наведені на рисунку 1 результати тесту ANOVA достовірно свідчать про те, що порівняно з 0 -гіпотезою при застосуванні NAVA на 2-й день лікування індекс резистентності мозкових артерій був достовірно вищим як на 2-й, так і на 3-й день дослідження, і ця закономірність була не випадковою, а саме внаслідок впливу досліджуваного режиму вентиляції.

Наступним етапом було порівняти вплив традиційних режимів вентиляції на показники церебральної перфузії. Для цього немовлята контрольної групи були стратифіковані за режимом ШВЛ на три підгрупи, а саме: $\mathrm{PC}-\mathrm{n}=152$, SIMV/PSV $-\mathrm{n}=16$ та PRVC $-\mathrm{n}=19$.

У таблиці 7 наведені результати тесту ANOVA щодо впливу режиму вентиляції SIMV/PSV на 2-й день на показники RI на 2-й і 3-й день лікування.

Результати тесту ANOVA, наведені в таблиці 7, показали, що немає значущої різниці між RI, виміряним на 2-й і 3-й день $(\mathrm{p}=0,504)$ у групах пацієнтів, яким проводили та не проводили вентиляцію в режимі SIMV/PSV, також не виявлено власне впливу SIMV/ PSV на рівні RI на 2-й і 3-й день лікування $(p=0,504)$. Так само RI не змінювався достовірно в пацієнтів, які перебували на вентиляції в режимі SIMV/PSV протягом 2-го і 3-го дня спостереження $(\mathrm{p}=0,446)$.

Результати мультиваріантного дисперсійного аналізу ступеня впливу режиму SIMV/PSV на зміни індексу RI на 2-й та 3-й день спостереження порівняно з 0-гіпотезою продемонстровані на рисунку 2.

Графік, представлений на рисунку 2, демонструе негативну динаміку індексу RI на фоні застосування режиму вентиляції SIMV/PSV протягом обох днів спостереження, але відмінності від 0-гіпотези виявились недостовірними.

Наступним було проаналізовано ступінь впливу режиму вентиляції РС на доплерівські індекси мозкового кровотоку. В таблиці 8 наведені результати тесту 


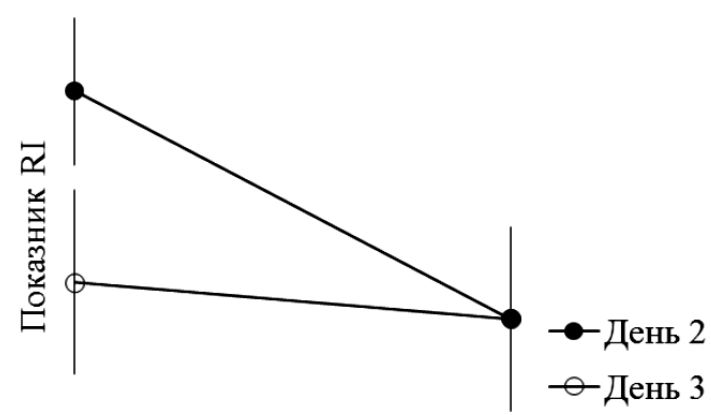

SIMV/PSV на 2-й день (0 - ні, 1 - так)

Рисунок 2. Порівняльний аналіз впливу режиму SIMV/PSV на зміни індексу RI на 2-й та 3-й день спостереження

ANOVA щодо зв'язку вентиляції в режимі РC на 2-й день з показниками RI на 2-й і на 3-й день лікування.

Результати тесту ANOVA, наведені в таблиці 8, свідчать, що немає значущої різниці між RI, виміряним на 2-й і 3 -й день $(\mathrm{p}=0,107)$ у групах пацієнтів, яким проводили і не проводили вентиляцію в режимі РС. Так само режим РС не призводив до статистично значущих змін рівня RI як на 2-й, так і на 3-й день лікування $(\mathrm{p}=0,423)$. Рівень RI також не змінювався в малюків, які отримували вентиляційну підтримку в режимі РС протягом з 2-го до 3-го дня спостереження $(\mathrm{p}=0,140)$.

Результати мультиваріантного дисперсійного аналізу ступеня впливу режиму РC на зміни індексу RI на 2-й та 3-й день спостереження порівняно з 0-гіпотезою продемонстровані на рисунку 3.

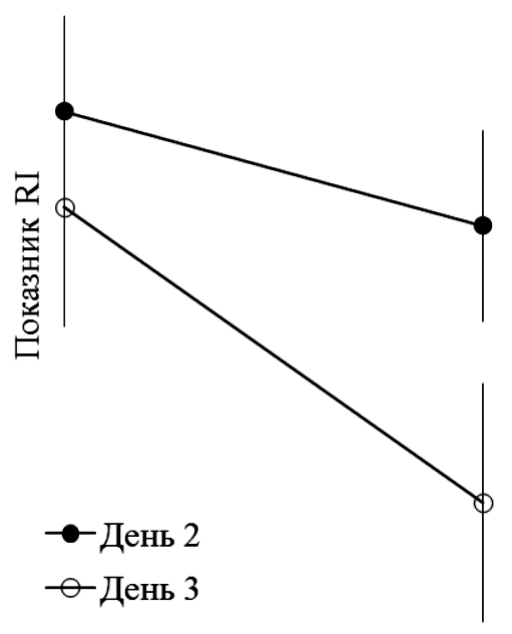

РС на 2-й день (0 - ні, 1 - так)

Рисунок 3. Порівняльний аналіз впливу режиму РС на зміни індексу RI на 2-й та 3-й день спостереження

\section{Таблиця 8}

Вплив застосування режиму $P C(n=152)$ на показники $R I$ на 2-й і 3-й день лікування

\begin{tabular}{|c|c|c|c|c|c|}
\hline Перемінні & $\begin{array}{c}\text { Сума } \\
\text { площі } \\
\text { відхилень }\end{array}$ & df & $\begin{array}{c}\text { Середня } \\
\text { площа } \\
\text { відхилень }\end{array}$ & $\mathbf{F}$ & p \\
\hline \multicolumn{6}{|c|}{ Ефекти в групах пацієнтів } \\
\hline RI & 0,026 & 1 & 0,026 & 2,626 & 0,107 \\
\hline $\begin{array}{l}\mathrm{RI} \cdot \mathrm{PC} \text { на } \\
2 \text {-й день }\end{array}$ & 0,007 & 1 & 0,007 & 0,646 & 0,423 \\
\hline Залишок & 1,704 & 169 & 0,010 & & - \\
\hline \multicolumn{6}{|c|}{ Ефекти між групами пацієнтів } \\
\hline РС на 2-й день & 0,031 & 1 & 0,031 & 2,197 & 0,140 \\
\hline Залишок & 2,377 & 169 & - & & - \\
\hline
\end{tabular}

Графік на рисунку 3 подібно до режиму SIMV/PSV відображає динаміку, яка демонструє, що режим вентиляції РC також погіршує індекс RI на 2-й та 3-й день лікування, але аналогічно ця відмінність порівняно 3 0-гіпотезою виявилась недостовірною.

Останньою підгрупою стратифікаційного аналізу були немовлята, яким ШВЛ проводили в режимі PRVC.

У таблиці 9 наведені результати тесту ANOVA щодо впливу режиму вентиляції PRVC на 2-й день на показники RI на 2-й і 3-й день лікування.

Результати тесту ANOVA, наведені в таблиці 9, демонструють відсутність значущої різниці між RI, виміряним на 2-й і 3-й день у групах пацієнтів, яким проводили і не проводили вентиляцію в режимі PRVC $(\mathrm{p}=0,291)$. Аналогічно не виявлено достовірних змін рівня RI як на 2-й, так і на 3-й день лікування $(\mathrm{p}=0,689)$. Рівень RI достовірно не змінювався в пацієнтів, яким проводилась вентиляція в режимі PRVC $(\mathrm{p}=0,601)$.

\section{Таблиця 9}

Вплив застосування режиму PRVC $(n=19)$ на показники RI на 2-й і 3-й день лікування

\begin{tabular}{|c|c|c|c|c|c|}
\hline Перемінні & $\begin{array}{c}\text { Сума } \\
\text { площі } \\
\text { відхилень }\end{array}$ & df & $\begin{array}{c}\text { Середня } \\
\text { площа } \\
\text { відхилень }\end{array}$ & $\mathbf{F}$ & p \\
\hline \multicolumn{6}{|c|}{ Ефекти в групах пацієнтів } \\
\hline $\mathrm{RI}$ & 0,011 & 1 & 0,011 & 1,123 & 0,291 \\
\hline $\begin{array}{l}\text { RI · PRVC на } \\
2 \text {-й день }\end{array}$ & 0,002 & 1 & 0,002 & 0,161 & 0,689 \\
\hline Залишок & 1,709 & 169 & 0,010 & & - \\
\hline \multicolumn{6}{|c|}{ Ефекти між групами пацієнтів } \\
\hline PRVC на 2-й день & 0,004 & 1 & 0,004 & 0,274 & 0,601 \\
\hline Залишок & 2,405 & 169 & 0,014 & & - \\
\hline
\end{tabular}




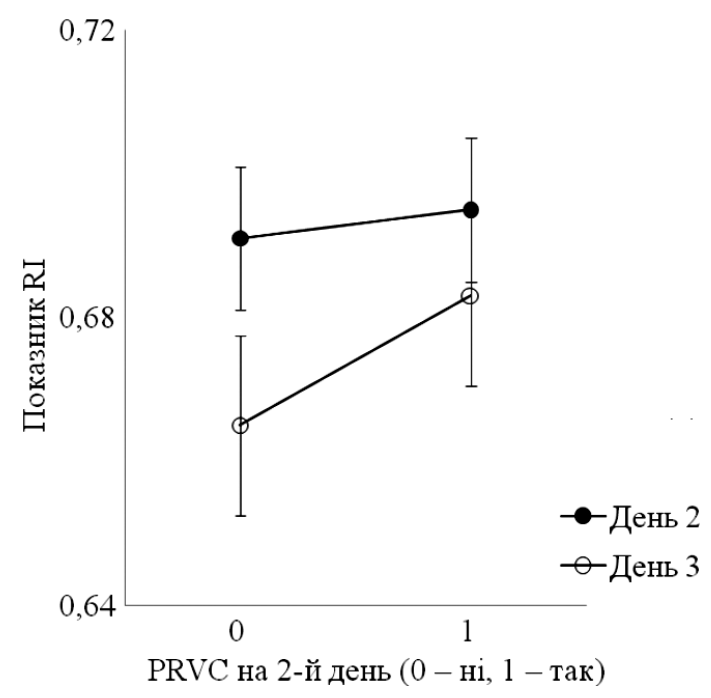

Рисунок 4. Порівняльний аналіз впливу режиму PRVC на зміни індексу RI на 2-й та 3-й день спостереження

Результати мультиваріантного дисперсійного аналізу ступеня впливу режиму PRVC на зміни індексу RI на 2 -й та 3-й день спостереження порівняно з 0 -гіпотезою продемонстровані на рисунку 4.

Дані аналізу, наведені на рисунку 5, свідчать, що порівняно з режимами SIMV/PSV та PC, застосування вентиляції в режимі PRVC щонайменше не погіршує стан церебральної перфузії. При порівнянні цього режиму з 0 -гіпотезою на 3-й день лікування навіть спостерігалась невелика позитивна динаміка з боку індексу RI, але на підставі проведеного тесту ANOVA стверджувати це достовірно не виявилось можливим $(p=0,601)$.

Таким чином, треба узагальнити, що застосування режиму вентиляції Neurally Adjusted Ventilatory Assist істотно покращує церебральну перфузію в новонароджених з ГІЕ. Доказом цього є статистично достовірна відмінність доплерівських індексів мозкового кровотоку RI та PI, які характеризують стан авторегуляції тонусу церебральних артерій, між немовлятами, які перебували на вентиляції в режимі NAVA, і тими, яким проводилась вентиляція в традиційних режимах, а саме: PC, SIMV/PSV або PRVC.

Перехресний мультиваріантний дисперсійний аналіз впливу традиційних режимів на мозковий кровообіг продемонстрував деяке зниження індексу резистентності мозкових артерій на фоні вентиляції в режимах SIMV/PSV та PC та нейтральний або слабопозитивний вплив на показник RI режиму вентиляції PRVC, хоча ці тенденції виявились статистично недостовірними.

Одним із вірогідних пояснень такої різниці поміж застосовуваними режимами може бути мінімізація коливань рівня $\mathrm{pCO}_{2}$ при застосуванні PRVC з контро- льованим хвилинним об'ємом вентиляції на противагу SIMV/PSV та PC, де дихальний об'єм є похідною величиною та може істотно коливатись при вентиляції в режимах із контрольованим тиском у дихальних шляхах при змінах комплаєнсу легень, що призводитиме до флуктуацій $\mathrm{pCO}_{2}$ як у бік гіперкапнії, так і гіпокапнії. Своєю чергою, рівень $\mathrm{pCO}_{2}$ відіграватиме одну з провідних ролей у впливі на стан авторегуляції тонусу мозкових артерій [40-42].

3 огляду на це режим NAVA істотно відрізняється від традиційної вентиляції завдяки тому, що фактично ступінь тиску підтримки дихання контролюється дитиною. Оскільки інспіраторний тиск є добутком множення фіксованого рівня NAVA level (см вод. ст.) на величину електричного збудження діафрагми Edi $(\mu \mathrm{V})$, то новонароджений сам регулює інтенсивність імпульсу, що виходить з дихального центру, базуючись на актуальній величині $\mathrm{pH}$ і $\mathrm{pCO}_{2}$ у реальному часі. Тому, як це підтверджують дані, представлені в огляді Andrade L. B. et al. (2017), значною перевагою використання режиму NAVA в дітей є стабільна нормокапнія протягом усього періоду вентиляційної підтримки [43].

Іншою складовою сприятливого впливу NAVA на церебральний кровообіг є оптимізація системної гемодинаміки. Оскільки на сьогодні, як свідчать дослідження Bordessoule A. et al. (2012), Schmidt M. et al. (2015) та Mortamet G. et al. (2017), це режим з найкращою синхронізацією «апарат - пацієнт», що обумовлює велику питому вагу спонтанного дихання щодо забезпечення дихального об'єму, а також, за даними Baez Hernandez N. et al. (2019), достовірно менший піковий інспіраторний тиск порівняно з традиційною вентиляцією (піковий тиск менше на 1,8 см вод. ст., $\mathrm{p}<0,001$; середній тиск у дихальних шляхах менше на 0,5 см вод. ст., $\mathrm{p}=0,009$ ), відповідно, сприяє мінімізації негативного впливу підвищеного внутрішньогрудного тиску на венозне повернення крові та кращому діастолічному наповненню шлуночків серця. Таким чином, оптимізується системна гемодинаміка, що забезпечує адекватну системну та церебральну перфузію [44-47].

Отримані результати частково збігаються з результатами досліджень Kallio M. et al. (2016), які вивчали застосування NAVA при гострому респіраторному дистрес-синдромі в новонароджених і дійшли висновку про безпечність його використання, але це дослідження стосувалось недоношених немовлят 28-36 тижнів гестації [48]. Також були опубліковані результати роботи Shetty S. et al. (2017), які продемонстрували покрашення індексу оксигенації (OI) при проведенні вентиляції NAVA порівняно з іншими режимами (OI 7,9 на NAVA порівняно 3 11,1 на режимі Assist/Control, аналогу PC $(\mathrm{p}=0,0007))$. Ці дані також можуть пояснювати позитивний вплив NAVA на гемодинаміку внаслідок оптимізації системного транспорту кисню. Залежність від кисню також була нижчою $\left(\mathrm{FiO}_{2} 0,36\right.$ vs 0,45 ; 
$\mathrm{p}=0,007)$, але це дослідження так само проводилось у недоношених малюків 22-27 тижнів гестації [49].

Кокранівський метааналіз досліджень NAVA в новонароджених, проведений Rossor T. E. et al. (2017), не дав остаточної відповіді на питання щодо впливу NAVA на мозкову перфузію та наслідки лікування ГІЕ у вигляді церебральної лейкомаляції [50]. Тобто для отримання остаточної відповіді на питання, наскільки впливає режим Neurally Adjusted Ventilatory Assist на мозкову перфузію, перебіг і наслідки помірної і тяжкої ГІЕ в доношених новонароджених, потрібно провести додаткові мультицентрові рандомізовані контрольовані дослідження.

\section{Висновки}

- Режим вентиляції Neurally Adjusted Ventilatory Assist $\epsilon$ безпечним для застосування в новонароджених і має кращий вплив на індекси церебральної перфузії в гострому періоді ГІЕ порівняно з традиційними режимами вентиляція, зокрема PC, SIMV/PSV та PRVC.

- Механізм покращення мозкового кровотоку на фоні NAVA очевидно полягає у відсутності негативного впливу на системну гемодинаміку, оптимальній синхронізації взаємодії з пацієнтами та відсутності суттєвих коливань рівня $\mathrm{CO}_{2}$, але потребує додаткових досліджень для остаточного уточнення.

- Не виявлено достовірних відмінностей щодо впливу на перфузію головного мозку між традиційними режимами з контролем тиску, що не дозволяє дійти висновку стосовно переваг того або іншого режиму в гострому періоді неонатальної ГIЕ.

\section{Список використаних джерел References}

1. Foster JP, Buckmaster A, Sinclair L, Lees S, Guaran R. Nasal continuous positive airway pressure (nCPAP) for term neonates with respiratory distress.Cochrane Database of Systematic Reviews. 2015;11:CD011962. https://doi. org/10.1002/14651858.CD011962.

2. Dewez JE, van den Broek N. Continuous positive airway pressure (CPAP) to treat respiratory distress in newborns in low- and middle-income countries. Trop Doct. 2017;47(1):19-22. https://doi. org/10.1177/0049475516630210.

3. Levene MI, de Vries L. Hypoxic-ischemic encephalopathy. In: Martin RJ, Fanaroff AA, Walsh MC, editors. Fanaroff and Martin's neonatal-perinatal medicine: diseases of the fetus and infant. 9th ed. St. Louis, Missoury: Elseiver Mosby Inc.; 2011. p. 952-975.

4. Zanelli SA, Stanley DP. Hypoxic-ischemic encephalopathy [Internet]. 2018 [Epub 2018 Jul 18]. Available from: https:// emedicine.medscape.com/article/973501-overview\#a8

5. Verma P, Kalraiya A. Respiratory compliance of newborns after birth and their short-term outcomes. Int J Contemp Pediatr. 2017;4(2):620-624. https://doi. org/10.18203/2349-3291.ijcp20170720
6. Goldsmith JP, Karotkin E, Suresh G, Keszler M. Assisted Ventilation of the Neonate, 6th Edition. Evidence-Based Approach to Newborn Respiratory Care. Elsevier; 2017.

7. Tiffany LB. Assisted ventilation of the neonate. JAMA. 2012;307(22):2437. https://doi.org/10.1001/ jama.307.22.2437-a

8. Pappas A, Shankaran S, Laptook AR, Langer JC, Bara R, Ehrenkranz RA, et al. Hypocarbia and adverse outcome in neonatal hypoxic-ischemic encephalopathy. J Pediatr. 2011;158(5):752-8. https://doi.org/10.1016/j. jpeds.2010.10.019.

9. Bancalari E, Claure N. Advances in respiratory support for high risk newborn infants. Maternal Health, Neonatology and Perinatology. 2015;1:13. https://doi.org/10.1186/ s40748-015-0014-5

10. Gupta S, Janakiraman S. Volume ventilation in neonates. Paediatrics and Child Health. 2018;8(1):1-5. https://doi. org/10.1016/j.paed.2017.09.004

11. Chitty H, Sinha S. Volume-targeted ventilation in newborn infants. Clinical Practice. 2015;11(1):8-12.

12. Krieger TJ, Wald M. Volume-targeted ventilation in the neonate: benchmarking ventilators on an active lung model. Pediatr Crit Care Med. 2017;18(3):241-8. https://doi. org/10.1097/PCC.0000000000001088

13. Klingenberg C, Wheeler KI, McCallion N, Morley CJ, Davis PG. A comparison of volume-targeted ventilation modes with traditional pressure-limited ventilation modes for newborn babies. Cochrane Database Syst Rev. 2017;10:CD003666. https://doi.org/10.1002/14651858. CD003666.pub4

14. Wang C, Guo L, Chi C, Wang X, Guo L, Wang W, et al. Mechanical ventilation modes for respiratory distress syndrome in infants: a systematic review and network metaanalysis. Crit Care. 2015;19:108. https://doi.org/10.1186/ s13054-015-0843-7

15. Greenough A, Murthy V, Milner AD, Rossor TE, Sundaresan A. Synchronized mechanical ventilation for respiratory support in newborn infants. Cochrane Database Syst Rev. 2016;9:CD000456. https://doi. org/10.1002/14651858.cd000456.pub4.CD000456

16. Rocha G, Soares P, Gonzalves A, Silva AI, Almeida D, Figueiredo S, et al. Respiratory care for the ventilated neonate.Canadian RespiratoryJournal.2018;2018:7472964. https://doi.org/10.1155/2018/7472964

17. Guthrie SO, Lynn C, Lafleur BJ, Donn SM, Walsh WF. A crossover analysis of mandatory minute ventilation compared to synchronized intermittent mandatory ventilation in neonates. J Perinatol. 2005;25(10):643-6. https://doi.org/10.1038/sj.jp.7211371

18. Claure N, Bancalari E. New modes of mechanical ventilation in the preterm newborn: evidence of benefit. Arch Dis Child Fetal Neonatal Ed. 2007;92(6):F508F512. https://doi.org/10.1136/adc.2006.108852

19. Serra A, Stronati M. Pressure support ventilation in neonatal age: lights and shadows. Pediatr Med Chir. 2005;27(6):13-18. PMID: 16922007.

20. Rozö JC, Krüger T. Pressure support ventilation - a new triggered ventilation mode for neonates. Lübeck: Dräger Medizintechnik GmbH; 2015. 
21. Hokenson MA, Shepherd EG. Neonatal pressure support ventilation: are we doing what we think we are doing? Respiratory Care. 2014;59(10):1606-7. https://doi. org/10.4187/respcare.03616.

22. El-Rahman Ali AA, El-Razik El Wahsha RA, El-Sattar Aghaa MA, Tawadroosb BB. Pressure regulated volume controlled ventilation versus synchronized intermittent mandatory ventilation in COPD patients suffering from acute respiratory failure. Egyptian Journal of Chest Diseases and Tuberculosis. 2016;65(1):121-5. https://doi. org/10.1016/j.ejcdt.2015.08.004

23. Stein H, Firestone K. Application of neurally adjusted ventilatory assist in neonates. Semin Fetal Neonatal Med. 2014;19(1):60-9. https://doi.org/10.1016/j. siny.2013.09.005

24. Kallio M, Peltoniemi O, Anttila E, Pokka T, Kontiokari T. Neurally adjusted ventilatory assist (NAVA) in pediatric intensive care - a randomized controlled trial. Pediatr Pulmonol. 2015;50(1):55-62. https://doi.org/10.1002/ ppul.22995

25. Ducharme-Crevier L, Beck J, Essouri S, Jouvet P, Emeriaud G. Neurally adjusted ventilatory assist (NAVA) allows patient-ventilator synchrony during pediatric noninvasive ventilation: a crossover physiological study. Crit Care. 2015;19:44. https://doi.org/10.1186/s13054-015-0770-7

26. Goligher EC, Douflй G, Fan E.Update in mechanical ventilation, sedation, and outcomes 2014. Am J Respir Crit Care Med. 2015;191(12):1367-73. https://doi. org/10.1164/rccm.201502-0346UP

27. Liet J-M, Barriure F, Gaillard-Le Roux B, Bourgoin P, Legrand A, Joram N. Physiological effects of invasive ventilation with neurally adjusted ventilatory assist (NAVA) in a crossover study. BMC Pediatr. 2016;16:180. https:// doi.org/10.1186/s12887-016-0717-4

28. Arca MJ, Uhing M, Wakeham M. Current concepts in acute respiratory support for neonates and children. Semin Pediatr Surg. 2015;24(1):2-7. https://doi.org/10.1053/j. sempedsurg.2014.11.001

29. Rossor TE, Shetty S, Greenough A. Neurally adjusted ventilatory assist for neonatal respiratory support. Cochrane Database of Systematic Reviews. 2016;6:CD012251. https://doi.org/10.1002/14651858.CD012251

30. Garcia-Mucoz Rodrigo F, Rivero Rodriguez S, Florido Rodriguez A, Martin Cruz FG, Diaz Pulido R. [Successful weaning and extubation in the premature newborn using neuraly adjusted ventilatory assist]. An Pediatr (Barc). 2015;82(1):e126-e130. (Article in Spanish). https://doi. org/10.1016/j.anpedi.2014.01.024

31. Piastra M, De Luca D, Costa R, Pizza A, De Sanctis R, Marzano L, et al. Neurally adjusted ventilatory assist vs pressure support ventilation in infants recovering fromsevere acute respiratory distress syndrome: Nested study. J Crit Care. 2014;29(2):312. e1-5. https://doi.org/10.1016/j. jcrc.2013.08.006

32. Beck J, Emeriaud G, Liu Y, Sinderby C. Neurally-adjusted ventilatory assist (NAVA) in children: a systematic review. Minerva Anestesiol. 2016;82(8):874-83. PMID:26375790.

33. Kadivar M, Mosayebi Z, Sangsari R, Soltan Alian H, Jedari Attari S. Neurally Adjusted Ventilatory Assist in neonates: a research study. Journal of Comprehensive
Pediatrics. 2018;9(3):e62297. https://doi.org/10.5812/ compreped.62297

34. Narchi H, Chedid F. Neurally adjusted ventilator assist in very low birthweight infants: Current status. World J Methodol. 2015;5(2):62-7. https://doi.org/10.5662/wjm. v5i2.62

35. Proisy M, Mitra S, Uria-Avellana C, Sokolska M, Robertson NJ, Le Jeune F. Brain perfusion imaging in neonates: an overview. American Journal of Neuroradiology. 2016;37(10):1766-73. https://doi.org/https://doi. org/10.3174/ajnr.A4778

36. Wong F. Cerebral blood flow measurements in the neonatal brain. Prenatal and Postnatal Determinants of Development. 2016;109:69-87. https://doi.org/10.1007/978-1-49393014-2_5

37. Orman G, Benson JE, Kweldam CF, Bosemani T, Tekes A, de Jong ME. Neonatal head ultrasonography today: a powerful imaging tool. Journal of Neuroimaging. 2015;25(1):31-55. https://doi.org/10.1111/jon.12108

38. Gerner GJ, Burton VJ, Poretti A, Bosemani T, Cristofalo E, Tekes A, et al. Transfontanellar duplex brain ultrasonography resistive indices as a prognostic tool in neonatal hypoxic-ischemic encephalopathy before and after treatment with therapeutic hypothermia. Journal of Perinatology. 2016;36(3):202-6. https://doi.org/10.1038/ jp.2015.169

39. Elstad M, Whitelaw A, Thoresen M. Cerebral resistance index is less predictive in hypothermic encephalopathic newborns. Acta Paediatrica. 2011;100:1344-9. https://doi. org/10.1111/j.1651-2227.2011.02327.x

40. Schirmer-Mikalsen K, Vik A, Skogvoll E, Moen KG, Solheim O, Klepstad P. Intracranial pressure during Pressure Control and Pressure-Regulated Volume Control ventilation in patients with traumatic brain injury: A randomized crossover trial. Neurocrit Care. 2016;24(3):3341. https://doi.org/10.1007/s12028-015-0208-8

41. Arellano-Maric MP, Gregoretti C, Duiverman M, Windisch W. Long-term volume-targeted pressure-controlled ventilation: sense or nonsense? Eur Respir J. 2017;49(6). pii: 1602193. https://doi.org/10.1183/13993003.02193-2016

42. Ashworth L, Norisue Y, Koster M, Anderson J, Takada J, Ebisu H. Clinical management of pressure control ventilation: An algorithmic method of patient ventilatory management to address «forgotten but important variables». J Crit Care. 2018;43:169-82. https://doi.org/10.1016/j. jcrc.2017.08.046

43. Andrade LB, Ghedini RG, Dias AS, Piva JP. Neurally adjusted ventilatory assist in pediatrics: why, when, and how? Rev Bras Ter Intensiva. 2017;29(4):408-13. https:// doi.org/10.5935/0103-507X.20170064

44. Bordessoule A, Emeriaud G, Morneau S, Jouvet P, Beck J. Neurally adjusted ventilatory assist improves patient-ventilator interaction in infants as compared with conventional ventilation. Pediatr Res. 2012;72(2):194202. https://doi.org/10.1038/pr.2012.64

45. Schmidt M, Kindler F, Cecchini J, Poitou T, Morawiec E, Persichini R, et al. Neurally adjusted ventilatory assist and proportional assist ventilation both improve patientventilator interaction. Crit Care. 2015;19:56. https://doi. org/10.1186/s13054-015-0763-6 
46. Mortamet G, Larouche A, Ducharme-Crevier L, Flŭchelles $\mathrm{O}$, Constantin $\mathrm{G}$, Essouri S, et al. Patientventilator asynchrony during conventional mechanical ventilation in children. Ann Intensive Care. 2017;7(1):122. https://doi.org/10.1186/s13613-017-0344-8

47. Baez Hernandez N, Milad A, Li Y, Van Bergen AH. Utilization of Neurally Adjusted Ventilatory Assist (NAVA) mode in infants and children undergoing congenital heart surgery: a retrospective review. Pediatr Cardiol. 2019 Mar;40(3):563-9. https://doi.org/10.1007/s00246-0182027-0

48. Kallio M, Koskela U, Peltoniemi O, Kontiokari T, Pokka T, Suo-Palosaari M, et al. Neurally adjusted ventilatory assist (NAVA) in preterm newborn infants with respiratory distress syndrome-a randomized controlled trial. Eur $\mathbf{J}$ Pediatr. 2016;175(9):1175-83. https://doi.org/10.1007/ s00431-016-2758-y

49. Shetty S, Hunt K, Peacock J, Ali K, Greenough A. Crossover study of Assist Control ventilation and Neurally Adjusted Ventilatory Assist. Eur J Pediatr. 2017;176(4):509-13. https://doi.org/10.1007/s00431-017-2866-3

50. Rossor TE, Hunt KA, Shetty S, Greenough A. Neurally adjusted ventilatory assist compared to other forms of triggered ventilation for neonatal respiratory support. Cochrane Database Syst Rev. 2017;10:CD012251. https:// doi.org/10.1002/14651858.CD012251.pub2

\title{
Neurally Adjusted Ventilatory Assist Mode of Mechanical Ventilation in Neonates with Hypoxic-Ischemic Encephalopathy
}

\author{
Surkov D. M. \\ Dnipropetrovs’k Regional Children's Hospital, Dnipro, Ukraine
}

\begin{abstract}
Ventilator support is considered to be one of the key components of intensive care in term neonates with moderate to severe hypoxic-ischemic encephalopathy (HIE). Most authors recommend mechanical ventilation during the period of therapeutical hypothermia and after rewarming. Traditionally, pressure control ventilation has been used for ventilator support in neonates, but its disadvantage could be significant fluctuations in the $\mathrm{pCO}_{2}$ level which affects cerebral perfusion. An alternative may be the new neurally adjusted ventilatory assist (NAVA) mode of ventilation. There is a number of studies on using NAVA mode in newborns, both term and preterm, but its impact on cerebral perfusion compared to conventional modes is unknown.
\end{abstract}

The aim. To compare the impact of NAVA and conventional modes of mechanical ventilation on cerebral perfusion during the acute period of HIE in term neonates.

Materials and methods. Data on 205 term infants with Sarnat stage II-III HIE were collected during $\leq 72$ hours of life. All the neonates were distributed by simple open randomization in NAVA group $(n=18)$ and control group $(n=187)$, which was stratified on subgroups of pressure control $(P C)$ mode $(n=152)$, synchronized intermittent mandatory ventilation/ pressure support ventilation (SIMV/PSV) $(n=16)$ and pressure regulated volume control $(\mathrm{PRVC})(\mathrm{n}=19)$. Comparative analysis of the influence of NAVA and other modes on cerebral perfusion during the acute period of neonatal HIE has been performed.

Results and discussion. Compared to conventional modes of ventilation - PC, SIMV/PSV and PRVC, - NAVA group demonstrated significantly better Doppler indices of cerebral blood flow RI $(0.66$ [0.58-0.72] vs. 0.70 [0.67-0.74], $p=$ $0.021)$ and PI $(1.2[1.0-1.40]$ vs. $1.3[1.2-1.5], \mathrm{p}=0.032)$ on the 3rd day of treatment, at the end of therapeutic hypothermia period and at the start of rewarming. Subsequent analysis of variance (ANOVA) confirmed the positive impact of NAVA mode on cerebral perfusion $(\mathrm{p}=0.009)$, but didn't found significant correlations between Doppler indices of cerebral blood flow and PC $(p=0.140)$, SIMV/PSV $(p=0.446)$ and PRVC $(p=0.601)$ ventilation modes.

Conclusion. Compared to conventional modes of ventilation (PC, SIMV/PSV and PRVC), NAVA demonstrated better profile of influence on cerebral perfusion indices in term neonates during the acute period of HIE.

Keywords: hypoxia, ischemia, encephalopathy, mechanical ventilation, resistance index, NAVA.

Стаття надійшла в редакцію 01.04.2019 р. 